\title{
6-gingerol interferes with amyloid-beta (Aß) peptide aggregation
}

Elina Berntsson ${ }^{1}$, Suman Paul $^{1}$, Sabrina B. Sholts ${ }^{2}$, Jüri Jarvet ${ }^{1,3}$, Andreas Barth ${ }^{1}$, Astrid Gräslund ${ }^{1}$, Sebastian K. T. S. Wärmländer ${ }^{1, *}$

${ }^{1}$ Department of Biochemistry and Biophysics, Stockholm University, Sweden.

${ }^{2}$ Department of Anthropology, National Museum of Natural History, Smithsonian Institution, Washington, DC, USA.

${ }^{3}$ The National Institute of Chemical Physics and Biophysics, Tallinn, Estonia.

* Correspondence: seb@dbb.su.se; Tel.: +46-8-162444 


\begin{abstract}
Alzheimer's disease (AD) is the most prevalent age-related cause of dementia. AD affects millions of people worldwide, and to date there is no cure. The pathological hallmark of $\mathrm{AD}$ brains is deposition of amyloid plaques, which mainly consist of amyloid- $\beta(\mathrm{A} \beta)$ peptides, commonly 40 or 42 residues long, that have aggregated into amyloid fibrils. Intermediate aggregates in the form of soluble $A \beta$ oligomers appear to be highly neurotoxic. Cell and animal studies have previously demonstrated positive effects of the molecule 6-gingerol on AD pathology. Gingerols are the main active constituents of the ginger root, which in many cultures is a traditional nutritional supplement for memory enhancement. Here, we use biophysical experiments to characterize in vitro interactions between 6-gingerol and $A \beta_{40}$ peptides. Our experiments with atomic force microscopy imaging, and nuclear magnetic resonance and Thioflavin-T fluorescence spectroscopy, show that the hydrophobic 6-gingerol molecule interferes with formation of $A \beta_{40}$ aggregates, but does not interact with $A \beta_{40}$ monomers. Thus, together with its favourable toxicity profile, 6-gingerol appears to display many of the desired properties of an anti-AD compound.
\end{abstract}

Key Words: Alzheimer's disease; Amyloid aggregation; Neurodegeneration; Ginger; Therapeutics; Dementia 


\section{INTRODUCTION}

Alzheimer's disease (AD) is a progressive and currently incurable neurodegenerative disorder, and the leading cause of age-related dementia worldwide (Frozza et al., 2018; Querfurth and LaFerla, 2010). Although AD brains typically display signs of neuroinflammation and oxidative stress (Agostinho et al., 2010; Regen et al., 2017; Wang et al., 2014b), the main characteristic lesions in AD brains are extracellular amyloid plaques (Querfurth and LaFerla, 2010; Selkoe and Hardy, 2016), which mainly consist of insoluble fibrillar aggregates of amyloid- $\beta$ (A $\beta$ ) peptides (Querfurth and LaFerla, 2010).

The $A \beta$ peptides comprise $37-43$ residues and are intrinsically disordered in aqueous solution. They have limited solubility in water due to the hydrophobicity of the central and C-terminal segments, which may fold into a hairpin conformation upon aggregation (Abelein et al., 2014; Baronio et al., 2019). The charged N-terminal segment of $A \beta$ peptides is hydrophilic and interacts readily with cationic molecules and metal ions (Luo et al., 2014a; Owen et al., 2019; Wärmländer et al., 2013).

The $\mathrm{A} \beta$ fibrils and plaques that characterize AD neuropathology are the endproducts of $A \beta$ aggregation processes (Owen et al., 2019; Selkoe and Hardy, 2016) that involve extra- and/or intracellular formation of intermediate, soluble, and likely neurotoxic A $\beta$ oligomers (Luo et al., 2014b; Sengupta et al., 2016) which may transfer from neuron to neuron via e.g. exosomes (Sardar Sinha et al., 2018). Oligomers of $A \beta_{42}$ appear to be the most cell-toxic species (Sengupta et al., 2016). The formation of $A \beta$ oligomers is influenced by interactions with various entities such as cellular membranes, small molecules, other proteins, and metal ions (Luo et al., 2016a, b; Owen et al., 2019; Wärmländer et al., 2019; Österlund et al., 2018a). Significant effort has been put into finding suitable molecules - i.e., drug candidates that may modulate the A $\beta$ aggregation processes (Leshem et al., 2019; Luo et al., 2013; Richman et al., 2013), but so far no drug has been approved (Frozza et al., 2018). 
Some investigations of potential anti-AD substances have focused on natural plant compounds, such as gingerols, which are phenolic phytochemical compounds present in the subterranean stem, or rhizome, of angiosperms of the ginger (Zingiberaceae) family (Wang et al., 2014a). Consumed worldwide as a spice and herbal medicine, the rhizome of ginger (Zingiber officinale) has demonstrated anti-inflammatory, antioxidant, antiemetic, analgesic, and antimicrobial effects (Sharifi-Rad et al., 2017). Ginger is a common ingredient in traditional healthy diets in many cultures (Iranshahy and Javadi, 2019; Khodaie and Sadeghpoor, 2015). According to Arabian folk wisdom, ginger improves memory and enhances cognition (Saenghong et al., 2012). Gingerols are generally considered to be safe for humans (Kaul and Joshi, 2001; Wang et al., 2014a). Yet, they are cytotoxic towards blood cancer and lung cancer cells (de Lima et al., 2018; Semwal et al., 2015), and in vitro studies have demonstrated positive effects also on bowel (Jeong et al., 2009), breast (Lee et al., 2008), ovary (Rhode et al., 2007), and pancreas cancer (Park et al., 2006).

The major pharmacologically-active variant is 6-gingerol, which has been associated with the prevention and treatment of neurodegenerative diseases such as AD (Choi et al., 2018; Jeong et al., 2013; Mohd Sahardi and Makpol, 2019; Wang et al., 2014a). Its chemical structure is shown in Fig. 1. The anti-oxidant and antiinflammatory properties of 6-gingerol are potentially useful against AD (Mohd Sahardi and Makpol, 2019), which may explain why 6-gingerol has been reported to reduce markers for neuroinflammation and oxidative stress, as well as decrease $A \beta$ levels, in mice and cell AD models (Halawany et al., 2017; Zeng et al., 2015). Little is however known about the molecular mechanisms by which 6-gingerol exerts its positive effects on the AD pathology models. For example, interactions between gingerols and $A \beta$ peptides have not been studied at the molecular level.

Here, we use biophysical techniques - liquid-phase fluorescence and nuclear magnetic resonance (NMR) spectroscopy together with solid-state atomic force microscopy (AFM) - to investigate possible in vitro interactions between 6-gingerol and $A \beta_{40}$ peptides, and how such interactions may affect the $A \beta_{40}$ aggregation and amyloid formation processes. 


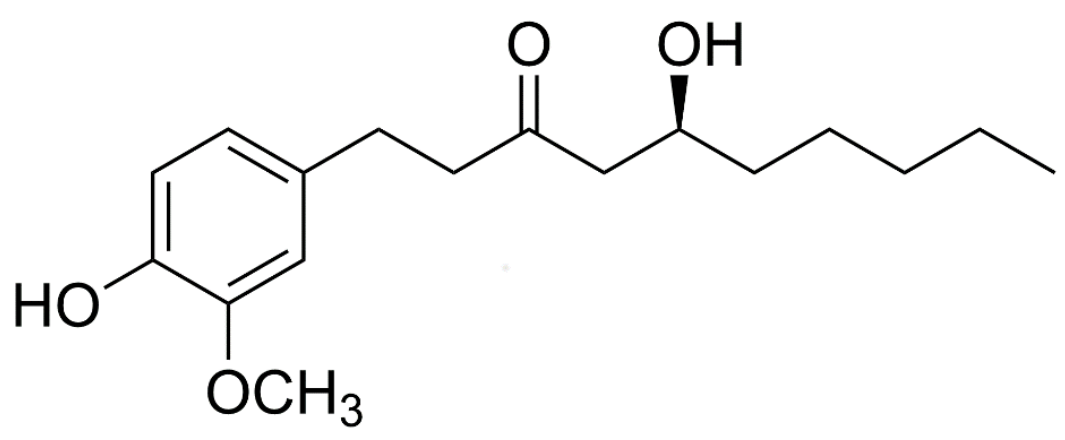

Figure 1. Chemical structure for the hydrophobic plant metabolite 6-gingerol. $\mathrm{MW}=$ $294.4 \mathrm{~g} / \mathrm{mol}$.

\section{MATERIALS AND METHODS}

\section{Reagents and sample preparation}

6-gingerol was purchased as a powder from Sigma-Aldrich Inc. (USA), and dissolved in DMSO (dimethyl sulfoxide).

Recombinant unlabeled or uniformly ${ }^{15} \mathrm{~N}$-labeled $\mathrm{A} \beta_{40}$ peptides, with the primary sequence

DAEFR $_{5} \mathrm{HDSGY}_{10} \mathrm{EVHHQ}_{15} \mathrm{KLVFF}_{20} \mathrm{AEDVG}_{25} \mathrm{SNKGA}_{30} \mathrm{IIGLM}_{35} \mathrm{VGGVV}_{40}$, were purchased lyophilized from AlexoTech AB (Umeå, Sweden). The peptides were stored at $-80{ }^{\circ} \mathrm{C}$ until used. The peptide concentration was determined by weight, and the peptide samples were dissolved to monomeric form immediately before each measurement. In brief, the peptides were dissolved in $10 \mathrm{mM}$ sodium hydroxide, $\mathrm{pH}$ 12 , at a $1 \mathrm{mg} / \mathrm{ml}$ concentration and sonicated in an ice-bath for at least three minutes to avoid having pre-formed aggregates in the peptide solutions. The peptide solution was then further diluted in $20 \mathrm{mM}$ buffer of either sodium phosphate or MES (2-[Nmorpholino]ethanesulfonic acid) at $\mathrm{pH}$ 7.35. All sample preparation steps were performed on ice.

\section{ThT fluorescence monitoring A $\beta$ aggregation kinetics}

To monitor the effect of 6-gingerol on $\mathrm{A} \beta_{40}$ aggregation kinetics, $15 \mu \mathrm{M}$ monomeric $A \beta_{40}$ peptides were incubated in $20 \mathrm{mM}$ MES buffer $\mathrm{pH} 7.35$ in the presence of five different concentrations of 6-gingerol $(15,75,150,300$, and 1500 
$\mu \mathrm{M})$ together with DMSO $(0.1 \%, 0.6 \%, 1 \%, 2 \%$ and $10 \%$; vol/vol $)$. Additionally, a control sample without 6-gingerol but containing 2\% DMSO was prepared. All samples contained $50 \mu \mathrm{M}$ Thioflavin $\mathrm{T}(\mathrm{ThT})$, which is a benzothiazole dye that displays increased fluorescence intensity when bound to amyloid aggregates (Gade Malmos et al., 2017). The ThT dye was excited at $440 \mathrm{~nm}$, and the fluorescence emission at $480 \mathrm{~nm}$ was measured every five minutes in a 96-well plate in a FLUOstar Omega microplate reader (BMG LABTECH, Germany). The sample volume in each well was $35 \mu 1$, four replicates per condition were measured, the temperature was +37 ${ }^{\circ} \mathrm{C}$, and each five-minute cycle involved 140 seconds of shaking at $200 \mathrm{rpm}$. The assay was repeated three times.

Even though the ThT fluorescence signal reached its maximum value after about seven hours, the incubation in the microplate reader continued for 72 hours to allow the samples to aggregate into mature fibrils that could be observed with AFM imaging (below).

To derive parameters for the aggregation kinetics, the ThT fluorescence curves were fitted to the sigmoidal equation 1 :

$$
F(t)=F_{0}+m_{0} \cdot t+\frac{F_{\infty}+m_{\infty} \cdot t}{1+\exp -\left[\left(t-\tau_{1 / 2}\right) / \tau_{\text {elon }}\right]}
$$

where $F_{0}$ and $F_{\infty}$ are the intercepts of the initial and final fluorescence intensity baselines, $m_{0}$ and $m_{\infty}$ are the slopes of the initial and final baselines, $\tau_{\frac{1}{2}}$ is the time needed to reach halfway through the elongation phase (i.e., aggregation half-time), and $\tau_{\text {elon }}$ is the elongation time constant (Gade Malmos et al., 2017). The apparent maximum rate constant for fibrillar growth, $r_{\max }$, is defined as $1 / \tau_{\text {elon }}$.

\section{Atomic force microscopy (AFM) imaging of $\mathbf{A} \boldsymbol{\beta}$ fibrils}

Samples for AFM imaging were taken from the samples used in the ThT fluorescence measurements, after $72 \mathrm{~h}$ of incubation. AFM images were recorded for the two control samples of $15 \mu \mathrm{MA} \beta_{40}$ in MES buffer, with and without $2 \%$ added DMSO, and for the three samples of $15 \mu \mathrm{M} A \beta_{40}$ together with $15 \mu \mathrm{M}, 75 \mu \mathrm{M}$, and 
$300 \mu \mathrm{M}$ of 6-gingerol. Droplets of $1 \mu \mathrm{l}$ incubated sample were placed on fresh silicon wafers (Siegert Wafer GmbH, Germany) and allowed to sit for 2 minutes. Next, $10 \mu \mathrm{l}$ Milli-Q water was added to the droplets, and all excess fluid was removed immediately with a lint-free wipe. The wafers were left to dry in a covered container to protect from dust, and AFM images were recorded on the same day. A neaSNOM scattering-type near-field optical instrument (Neaspec GmbH, Germany) was used to collect the AFM images under tapping mode ( $\Omega: 280 \mathrm{kHz}$, tapping amplitude 50-55 $\mathrm{nm}$ ) using Pt/Ir-coated monolithic ARROW-NCPt Si tip (NanoAndMore GmbH, Germany) with tip radius $<10 \mathrm{~nm}$. Images were acquired on 2.5 x $2.5 \mu \mathrm{m}$ scan-areas (200 x 200-pixel size) under optimal scan-speed (i.e., $2.5 \mathrm{~ms} /$ pixel), and both topographic and mechanical phase images were recorded. Images were minimally processed using the Gwyddion software where a basic plane levelling was performed (Nečas and Klapetek, 2012).

\section{Nuclear magnetic resonance (NMR) spectroscopy}

An Avance 700 MHz NMR spectrometer (Bruker Inc., USA) equipped with a cryogenic probe was used to record $2 \mathrm{D}^{1} \mathrm{H}_{-}{ }^{15} \mathrm{~N}-\mathrm{HSQC}$ spectra at $+20{ }^{\circ} \mathrm{C}$ of $92.4 \mu \mathrm{M}$ monomeric ${ }^{15} \mathrm{~N}$-labeled $\mathrm{A} \beta_{40}$ peptides $(500 \mu \mathrm{l})$, either in only $20 \mathrm{mM}$ sodium phosphate buffer at pH $7.35\left(90 / 10 \mathrm{H}_{2} \mathrm{O} / \mathrm{D}_{2} \mathrm{O}\right)$, or in phosphate buffer together with 50 mM SDS (sodium dodecyl sulphate) detergent. As the critical micelle concentration (CMC) for SDS is around $8 \mathrm{mM}$ (Österlund et al., 2018b), most of the SDS was present as micelles. Both samples were titrated, first with additions of pure DMSO, and then by 6-gingerol dissolved in DMSO. The NMR data was processed with the Topspin version 3.6.2 software, and the A $\beta_{40}$ HSQC crosspeak assignment in buffer (Danielsson et al., 2006) and in SDS micelles (Jarvet et al., 2007) is known from previous work.

\section{RESULTS}

\section{ThT fluorescence kinetics}


Fig. 2 shows ThT fluorescence intensity curves for $15 \mu \mathrm{M} A \beta_{40}$ peptides, incubated in the presence of varying concentrations of 6-gingerol and DMSO. These curves reflect the formation of amyloid aggregates, and they all display a generally sigmoidal shape. Fitting Eq. 1 to the curves produces the kinetic parameters $\tau_{1 / 2}, r_{\max }$, and $\tau_{\text {lag }}$ (Table 1). Addition of DMSO alone, which was used to dissolve the 6gingerol, has minor effects on the aggregation kinetics, i.e. by slightly increasing the lag time from 0.94 to $0.98 \mathrm{hrs}$ and decreasing the aggregation half time from 2.2 to 1.9 hrs (Fig. 2, Table 1). With 6-gingerol, some additions produce aggregation kinetics that differ from the control samples. For example, addition of $75 \mu \mathrm{M}$ 6-gingerol appears to slow down the aggregation $\left(\tau_{\text {lag }}=1.3 \mathrm{~h} ; \tau_{1 / 2}=3.3 \mathrm{~h}\right)$, while addition of 150 $\mu \mathrm{M}$ 6-gingerol appears to speed up the aggregation $\left(\tau_{\text {lag }}=0.5 \mathrm{~h} ; \tau_{1 / 2}=1.7 \mathrm{~h}\right)$. There is however variation in these measurements, and there is no overall trend of faster or slower kinetics for the series of 6-gingerol additions. Thus, these data indicate that 6gingerol has no systematic effect on $\mathrm{A} \beta_{40}$ aggregation or amyloid formation.

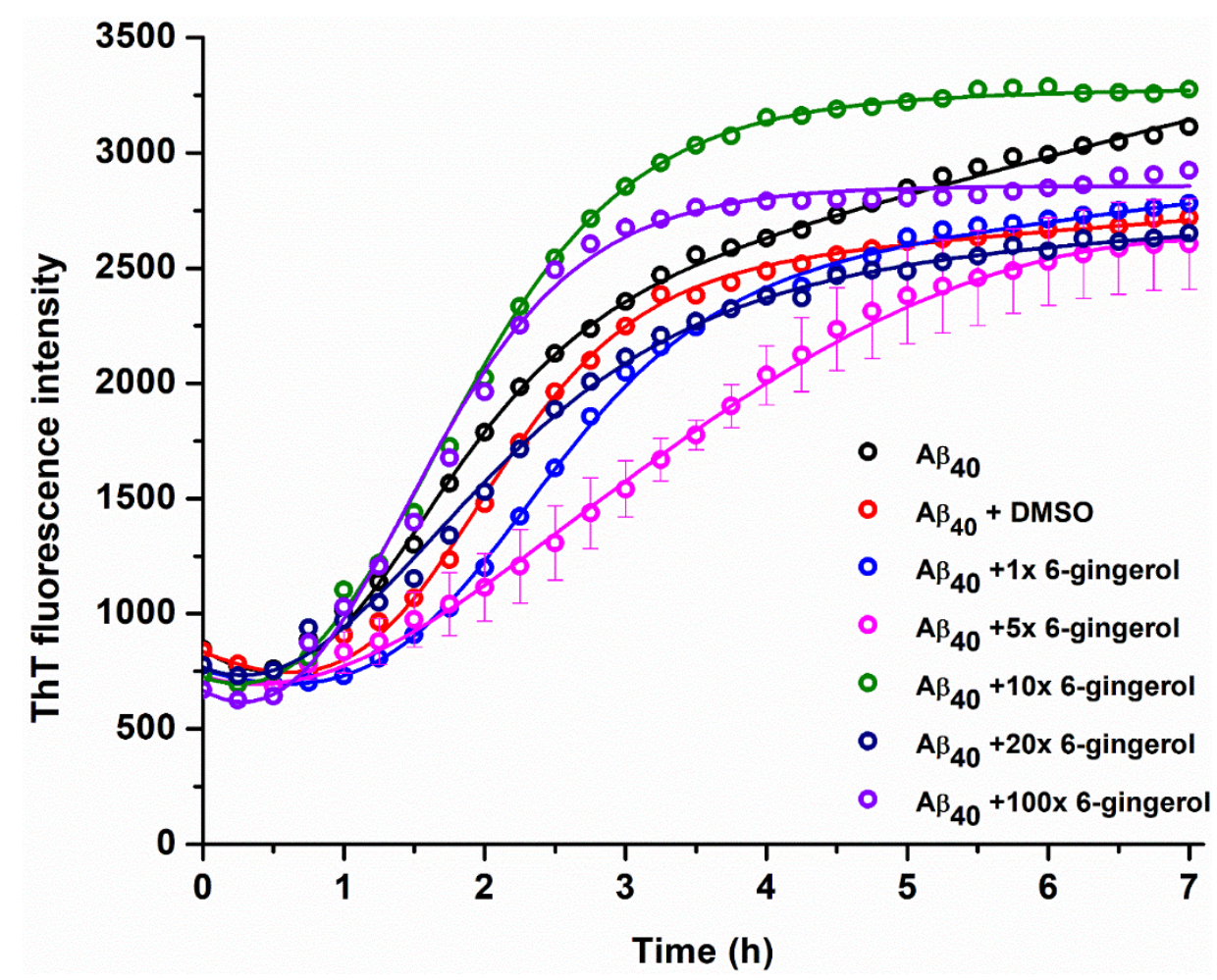

Figure 2. ThT fluorescence curves showing the aggregation kinetics of $15 \mu \mathrm{M} A \beta_{40}$ in 20 mM MES buffer, pH 7.35, at $37^{\circ} \mathrm{C}$. Black: buffer only; Red: 2\% DMSO; Blue: 15

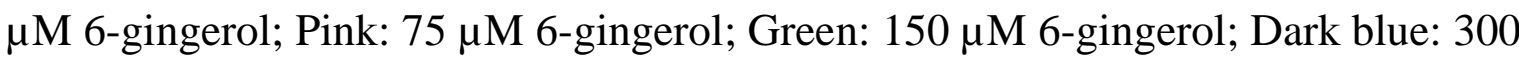


$\mu \mathrm{M}$ 6-gingerol; and Purple: $1500 \mu \mathrm{M}$ 6-gingerol. Average curves from four replicates are shown.

Table 1. Kinetic parameters $\left(\tau_{1 / 2}, \tau_{\mathrm{lag}}\right.$, and $\left.r_{\max }\right)$ for fibril formation of $15 \mu \mathrm{M} \mathrm{A} \beta_{40}$ peptides, derived from fitting Eq. 1 to the ThT fluorescence curves shown in Fig. 2.

\begin{tabular}{|l|l|l|l|l|l|l|l|}
\hline & $\begin{array}{l}\mathrm{A} \beta \text { control } \\
\text { in buffer }\end{array}$ & $\begin{array}{l}\mathrm{A} \beta \text { control in } \\
2 \% \mathrm{DMSO}\end{array}$ & $\begin{array}{l}+15 \mu \mathrm{M} \\
\text { 6-gingerol }\end{array}$ & $\begin{array}{l}+75 \mu \mathrm{M} \\
6 \text {-gingerol }\end{array}$ & $\begin{array}{l}+150 \mu \mathrm{M} \\
6 \text {-gingerol }\end{array}$ & $\begin{array}{l}+300 \mu \mathrm{M} \\
\text { 6-gingerol }\end{array}$ & $\begin{array}{l}+1500 \mu \mathrm{M} \\
\text { 6-gingerol }\end{array}$ \\
\hline$\tau_{1 / 2}$ (hours) & $2.17 \pm 0.1$ & $1.95 \pm 0.03$ & $2.1 \pm 0.04$ & $3.34 \pm 0.08$ & $1.7 \pm 0.06$ & $2.03 \pm 0.07$ & $1.80 \pm 0.05$ \\
\hline$\tau_{\text {lag }}$ (hours) & $0.94 \pm 0.12$ & $0.98 \pm 0.08$ & $0.99 \pm 0.08$ & $1.35 \pm 0.12$ & $0.50 \pm 0.08$ & $0.96 \pm 0.13$ & $1.04 \pm 0.15$ \\
\hline$r_{\max }$ (hours $^{-1}$ ) & $1.62 \pm 0.06$ & $2.05 \pm 0.07$ & $1.80 \pm 0.07$ & $1.01 \pm 0.07$ & $1.66 \pm 0.05$ & $1.86 \pm 0.11$ & $2.69 \pm 0.17$ \\
\hline
\end{tabular}

\section{AFM imaging}

AFM images were recorded for some of the samples used in the ThT fluorescence measurements, i.e. the two control samples of $15 \mu \mathrm{MA} \beta_{40}$ peptides in buffer with and without $2 \%$ DMSO, and the samples with additions of $15 \mu \mathrm{M}, 75 \mu \mathrm{M}$, and $300 \mu \mathrm{M}$ of 6-gingerol (Fig. 3). These samples were incubated for $72 \mathrm{~h}$, to ensure aggregation into the mature elongated fibrils seen in Fig. 3A. Incubation in the presence of $2 \%$ DMSO produced similar fibrils, although together with small nonfibrillar clumps (Fig. 3B). Somewhat similar results, although with even more clumps, were obtained for the samples incubated together with 15 and $75 \mu \mathrm{M} 6$-gingerol, which also contained $0.1 \%$ and $0.6 \%$ DMSO, respectively (Figs. 3C and 3D). The sample with $300 \mu \mathrm{M}$ of 6-gingerol and 2\% DMSO does however display a different morphology, as it clearly contains more amorphous clumps than elongated fibrils (Fig. 3E). When evaluating these samples, it is a confounding factor that DMSO appears to slightly affect the fibril formation. The sample with $300 \mu \mathrm{M} 6$-gingerol however contains 2\% DMSO (Fig. 3E), i.e. the same amount of DMSO as the control sample with DMSO (Fig. 3B). Thus, the different morphologies of the $A \beta_{40}$ aggregates in these two samples is clearly caused by the added 6-gingerol and not by the DMSO alone. 

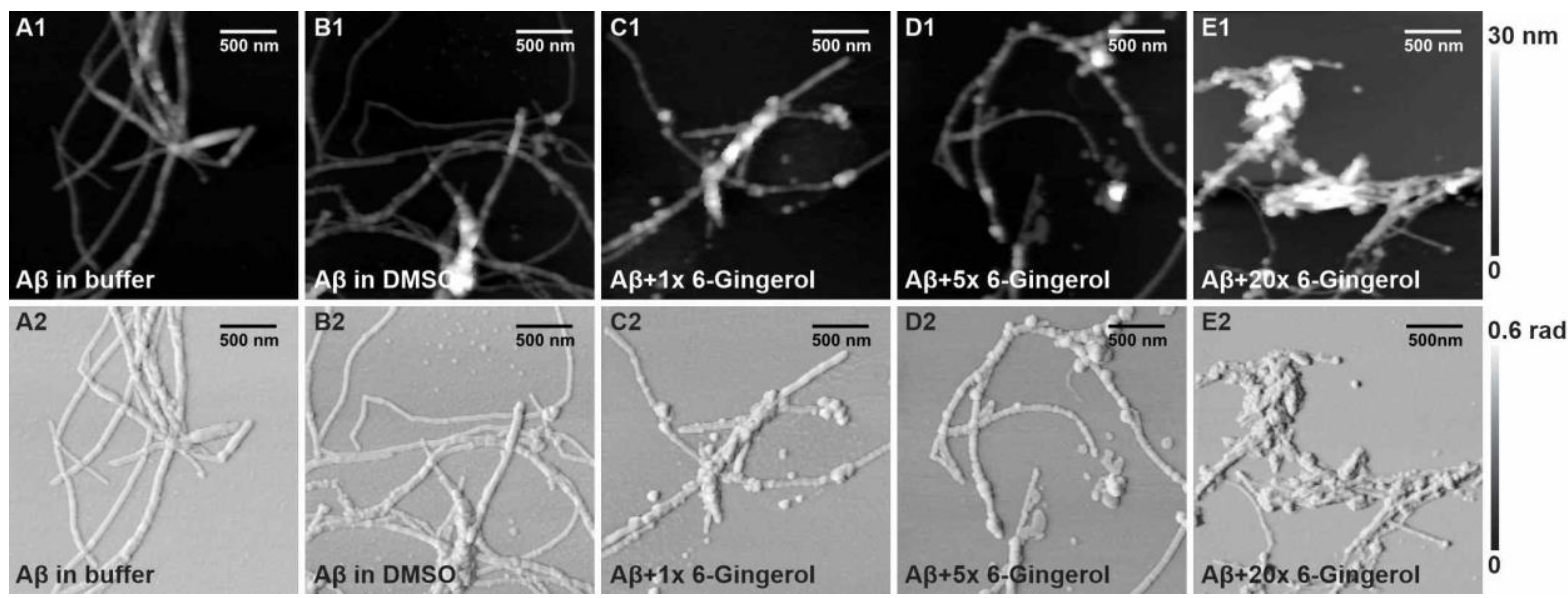

Figure 3. AFM images showing aggregates of $15 \mu \mathrm{M} A \beta_{40}$ peptide. (A) $A \beta_{40}$ in buffer. (B) $\mathrm{A} \beta_{40}$ in DMSO. (C) $\mathrm{A} \beta_{40}$ and $15 \mu \mathrm{M}$ 6-gingerol in DMSO, (D) $\mathrm{A} \beta_{40}$ and 75 $\mu \mathrm{M}$ 6-gingerol in DMSO, (E) A $\beta_{40}$ and $300 \mu \mathrm{M}$ 6-gingerol in DMSO. Top row: height profiles. Bottom row: mechanical phase images.

\section{NMR spectroscopy}

NMR experiments were conducted to investigate possible molecular interactions between 6-gingerol and the monomeric $A \beta_{40}$ peptide. The finger-print region of the ${ }^{1} \mathrm{H},{ }^{15} \mathrm{~N}$-HSQC spectrum of $92 \mu \mathrm{M}$ monomeric ${ }^{15} \mathrm{~N}$-labeled $\mathrm{A} \beta_{40}$ peptide is shown in Fig. 4 (blue spectrum), both for $A \beta_{40}$ in buffer and for $A \beta_{40}$ bound to SDS micelles. The SDS micelles were here used as a simple model for a membrane environment that is suitable for NMR studies (Österlund et al., 2018a; Österlund et al., 2018b). In both environments, addition of DMSO (2\% in the buffer sample and $3 \%$ in the sample with SDS micelles) induces chemical shifts of most crosspeaks (Fig. 4 , red spectra). This is consistent with previous NMR studies of A $\beta_{40}$ in DMSO (Wallin et al., 2017). Addition of 6-gingerol dissolved in DMSO increased the DMSO concentration to $4 \%$ in the buffer sample and to $5 \%$ in the sample with SDS micelles. This addition induces chemical shift changes for the NMR crosspeaks that are perfectly consistent with the changes induced by DMSO alone (Fig. 4, orange spectra). This shows that 6-gingerol does not have any strong interaction of its own with monomeric $A \beta_{40}$, neither in aqueous solution nor in a membrane environment. 

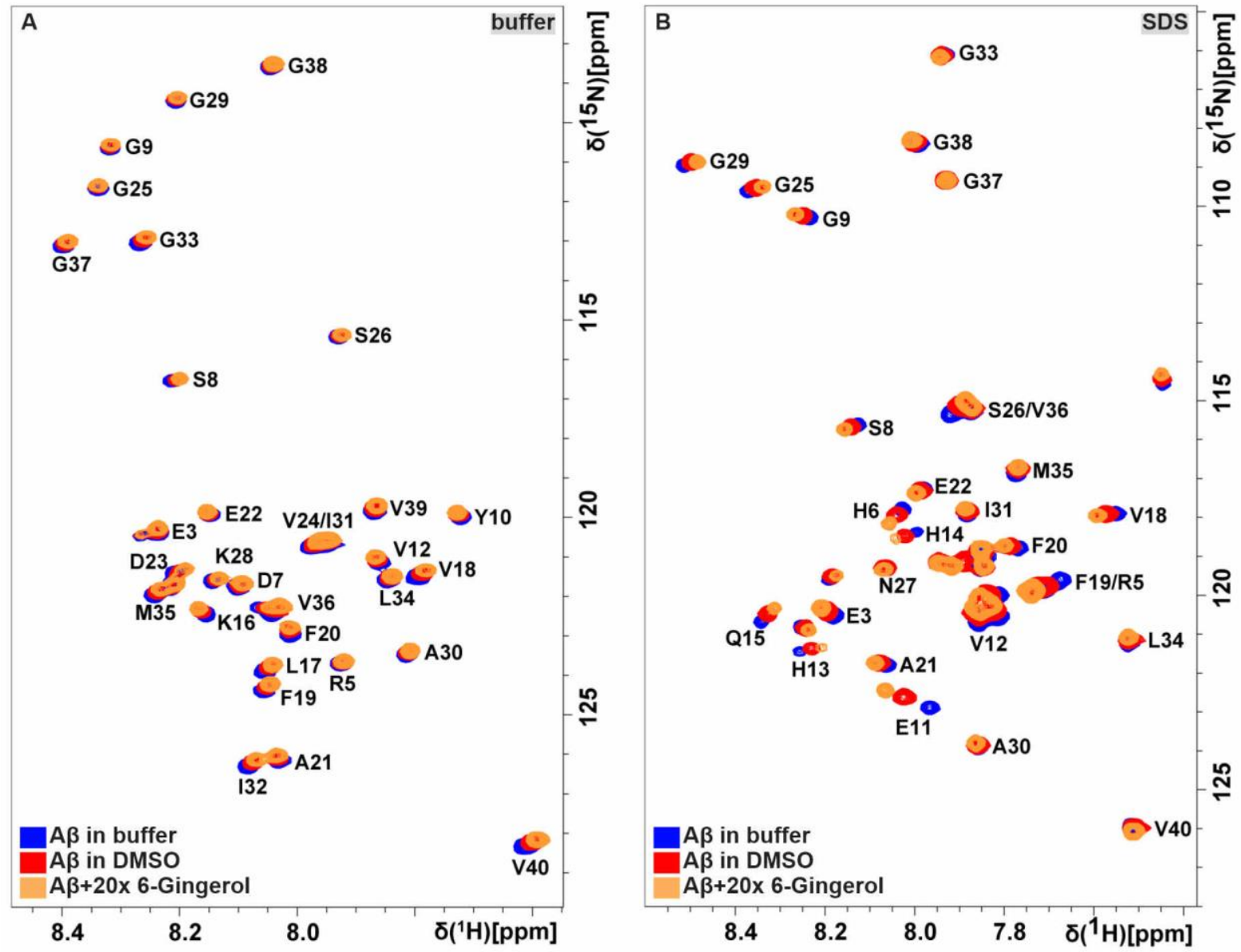

Figure 4. 2D NMR ${ }^{1} \mathrm{H},{ }^{15} \mathrm{~N}-\mathrm{HSQC}$ spectra recorded at $+20{ }^{\circ} \mathrm{C}$ for $92 \mu \mathrm{M}$ monomeric $\mathrm{A} \beta_{40}$ peptide in $20 \mathrm{mM}$ sodium phosphate buffer, $\mathrm{pH} 7.3$, for $(\mathrm{A}) \mathrm{A} \beta_{40}$ in buffer alone, and (B) $A \beta_{40}$ bound to micelles of $50 \mathrm{mM}$ SDS. The spectra were recorded before (blue) and after addition of DMSO (red), and then after addition of $1.84 \mathrm{mM} 6-$ gingerol in DMSO.

\section{DISCUSSION}

Given the ancient history and cultural importance of ginger in many parts of the world (Iranshahy and Javadi, 2019; Khodaie and Sadeghpoor, 2015; Saenghong et $a l ., 2012)$, it is desirable to understand the molecular mechanisms behind its proposed benefits to human health. Such mechanistic investigations may also expand ethnomedical research, which often focuses on population-level medical effects and exposure/uptake levels (Sholts et al., 2017; Wärmländer et al., 2011). 
Here, we show that 6-gingerol interferes with the aggregation mechanisms of $\mathrm{A} \beta_{40}$ peptide aggregation, by inducing aggregation into amorphous clumps rather than into elongated fibrils (Fig. 3). Our ThT fluorescence assays show that 6-gingerol has no systematic effect on the kinetics of the $A \beta_{40}$ aggregation process, and that approximately the same amount of amyloid aggregates is formed with and without 6gingerol (Fig. 2). From a medical perspective, however, the most important aspect of $\mathrm{A} \beta$ aggregation may not be the amount or speed of aggregation, but rather the properties of the aggregates. The neuronal death in AD appears to be mainly caused by small oligomeric A $\beta$ aggregates of unknown composition and structure (Luo et al., 2014b; Sardar Sinha et al., 2018; Sengupta et al., 2016) that might disrupt cell membranes (Wärmländer et al., 2019). Thus, the observed interference of 6-gingerol with the $A \beta$ aggregation processes could provide a molecular explanation of the previously observed beneficial effects of gingerols on cell and animal models of AD pathology (Choi et al., 2018; Halawany et al., 2017; Jeong et al., 2013; Mohd Sahardi and Makpol, 2019; Wang et al., 2014a; Zeng et al., 2015).

The NMR results show that 6-gingerol does not interact with monomeric $A \beta_{40}$, neither in aqueous solution nor in membrane-mimicking micelles. Thus, interaction appears to take place only when oligomers or larger aggregates have formed. This is not unreasonable, as $A \beta$ oligomers are considered to be more hydrophobic than the amphiphilic A $\beta$ monomers (Wärmländer et al., 2019), and thus more likely to interact with the hydrophobic 6-gingerol molecules. In fact, the ideal AD drug is a molecule that interferes with toxic $A \beta$ aggregates but not with the $\mathrm{A} \beta$ monomers, as the latter may have beneficial biological functions in their non-aggregated form (Dominy et al., 2019; Frozza et al., 2018; Querfurth and LaFerla, 2010; Rajendran and Annaert, 2012).

As a molecule that is non-toxic (Kaul and Joshi, 2001), easy to produce and administer, and small enough to easily pass through the blood-brain-barrier, 6gingerol has suitable properties for use as a drug. This study suggests that 6-gingerol may be used to combat $\mathrm{AD}$ by interfering with the aggregation of $\mathrm{A} \beta$ peptides. 


\section{CONFLICT OF INTEREST}

The authors declare no conflicts of interest.

\section{ACKNOWLEDGMENTS}

We thank Teodor Svantesson and Georgia Pilkington for helpful discussions and advice.

\section{REFERENCES}

Abelein, A., Abrahams, J. P., Danielsson, J., Gräslund, A., Jarvet, J., Luo, J., Tiiman, A. and Wärmländer, S. K. (2014). The hairpin conformation of the amyloid beta peptide is an important structural motif along the aggregation pathway. J Biol Inorg Chem 19, 623-634.

Agostinho, P., Cunha, R. A. and Oliveira, C. (2010). Neuroinflammation, oxidative stress and the pathogenesis of Alzheimer's disease. Curr Pharm Des 16, 2766-2778.

Baronio, C. M., Baldassarre, M. and Barth, A. (2019). Insight into the internal structure of amyloidbeta oligomers by isotope-edited Fourier transform infrared spectroscopy. Phys Chem Chem Phys 21, 8587-8597.

Choi, J. G., Kim, S. Y., Jeong, M. and Oh, M. S. (2018). Pharmacotherapeutic potential of ginger and its compounds in age-related neurological disorders. Pharmacol Ther 182, 56-69.

Danielsson, J., Andersson, A., Jarvet, J. and Gräslund, A. (2006). 15N relaxation study of the amyloid beta-peptide: structural propensities and persistence length. Magn Reson Chem $\mathbf{4 4} \mathrm{Spec}$ No, S114-121.

de Lima, R. M. T., Dos Reis, A. C., de Menezes, A. P. M., Santos, J. V. O., Filho, J., Ferreira, J. R. O., de Alencar, M., da Mata, A., Khan, I. N., Islam, A., Uddin, S. J., Ali, E. S., Islam, M. T., Tripathi, S., Mishra, S. K., Mubarak, M. S. and Melo-Cavalcante, A. A. C. (2018). Protective and therapeutic potential of ginger (Zingiber officinale) extract and [6]-gingerol in cancer: A comprehensive review. Phytother Res 32, 1885-1907.

Dominy, S. S., Lynch, C., Ermini, F., Benedyk, M., Marczyk, A., Konradi, A., Nguyen, M., Haditsch, U., Raha, D., Griffin, C., Holsinger, L. J., Arastu-Kapur, S., Kaba, S., Lee, A., Ryder, M. I., Potempa, B., Mydel, P., Hellvard, A., Adamowicz, K., Hasturk, H., Walker, G. D., Reynolds, E. C., Faull, R. L. M., Curtis, M. A., Dragunow, M. and Potempa, J. (2019). Porphyromonas gingivalis in Alzheimer's disease brains: Evidence for disease causation and treatment with smallmolecule inhibitors. Sci Adv 5, eaau3333.

Frozza, R. L., Lourenco, M. V. and De Felice, F. G. (2018). Challenges for Alzheimer's Disease Therapy: Insights from Novel Mechanisms Beyond Memory Defects. Front Neurosci 12, 37.

Gade Malmos, K., Blancas-Mejia, L. M., Weber, B., Buchner, J., Ramirez-Alvarado, M., Naiki, H. and Otzen, D. (2017). ThT 101: a primer on the use of thioflavin T to investigate amyloid formation. Amyloid 24, 1-16.

Halawany, A. M. E., Sayed, N. S. E., Abdallah, H. M. and Dine, R. S. E. (2017). Protective effects of gingerol on streptozotocin-induced sporadic Alzheimer's disease: emphasis on inhibition of beta-amyloid, COX-2, alpha-, beta - secretases and APH1a. Sci Rep 7, 2902. 
Iranshahy, M. and Javadi, B. (2019). Diet therapy for the treatment of Alzheimer's disease in view of traditional Persian medicine: A review. Iranian Journal of Basic Medical Sciences 22, 11021117.

Jarvet, J., Danielsson, J., Damberg, P., Oleszczuk, M. and Gräslund, A. (2007). Positioning of the Alzheimer Abeta(1-40) peptide in SDS micelles using NMR and paramagnetic probes. $J$ Biomol NMR 39, 63-72.

Jeong, C. H., Bode, A. M., Pugliese, A., Cho, Y. Y., Kim, H. G., Shim, J. H., Jeon, Y. J., Li, H., Jiang, H. and Dong, Z. (2009). [6]-Gingerol suppresses colon cancer growth by targeting leukotriene A4 hydrolase. Cancer Res 69, 5584-5591.

Jeong, J. K., Moon, M. H., Park, Y. G., Lee, J. H., Lee, Y. J., Seol, J. W. and Park, S. Y. (2013). Gingerolinduced hypoxia-inducible factor 1 alpha inhibits human prion peptide-mediated neurotoxicity. Phytother Res 27, 1185-1192.

Kaul, P. N. and Joshi, B. S. (2001). Alternative medicine: Herbal drugs and their critical appraisal - Part II. In Progress in Drug Research (E. Jucker, Ed., Vol. 57, pp. 1-75. Birkhäuser, Basel, Switzerland.

Khodaie, L. and Sadeghpoor, O. (2015). Ginger from ancient times to the new outlook. Jundishapur J Nat Pharm Prod 10, e18402.

Lee, H. S., Seo, E. Y., Kang, N. E. and Kim, W. K. (2008). [6]-Gingerol inhibits metastasis of MDA-MB231 human breast cancer cells. J Nutr Biochem 19, 313-319.

Leshem, G., Richman, M., Lisniansky, E., Antman-Passig, M., Habashi, M., Gräslund, A., Wärmländer, S. K. T. S. and Rahimipour, S. (2019). Photoactive chlorin e6 is a multifunctional modulator of amyloid-beta aggregation and toxicity via specific interactions with its histidine residues. Chem Sci 10, 208-217.

Luo, J., Mohammed, I., Wärmländer, S. K., Hiruma, Y., Gräslund, A. and Abrahams, J. P. (2014a). Endogenous polyamines reduce the toxicity of soluble abeta peptide aggregates associated with Alzheimer's disease. Biomacromolecules 15, 1985-1991.

Luo, J., Otero, J. M., Yu, C. H., Wärmländer, S. K., Gräslund, A., Overhand, M. and Abrahams, J. P. (2013). Inhibiting and reversing amyloid-beta peptide (1-40) fibril formation with gramicidin S and engineered analogues. Chemistry 19, 17338-17348.

Luo, J., Wärmländer, S. K., Gräslund, A. and Abrahams, J. P. (2014b). Alzheimer peptides aggregate into transient nanoglobules that nucleate fibrils. Biochemistry 53, 6302-6308.

Luo, J., Wärmländer, S. K., Gräslund, A. and Abrahams, J. P. (2016a). Cross-interactions between the Alzheimer Disease Amyloid-beta Peptide and Other Amyloid Proteins: A Further Aspect of the Amyloid Cascade Hypothesis. J Biol Chem 291, 16485-16493.

Luo, J., Wärmländer, S. K., Gräslund, A. and Abrahams, J. P. (2016b). Reciprocal Molecular Interactions between the Abeta Peptide Linked to Alzheimer's Disease and Insulin Linked to Diabetes Mellitus Type II. ACS Chem Neurosci 7, 269-274.

Mohd Sahardi, N. F. N. and Makpol, S. (2019). Ginger (Zingiber officinale Roscoe) in the Prevention of Ageing and Degenerative Diseases: Review of Current Evidence. Evid Based Complement Alternat Med 2019, 5054395.

Nečas, D. and Klapetek, P. (2012). Gwyddion: an open-source software for SPM data analysis. Central European Journal of Physics 10, 181-188.

Owen, M. C., Gnutt, D., Gao, M., Wärmländer, S. K. T. S., Jarvet, J., Gräslund, A., Winter, R., Ebbinghaus, S. and Strodel, B. (2019). Effects of in vivo conditions on amyloid aggregation. Chem Soc Rev 48, 3946-3996.

Park, Y. J., Wen, J., Bang, S., Park, S. W. and Song, S. Y. (2006). [6]-Gingerol induces cell cycle arrest and cell death of mutant p53-expressing pancreatic cancer cells. Yonsei Med J 47, 688-697.

Querfurth, H. W. and LaFerla, F. M. (2010). Alzheimer's disease. N Engl J Med 362, 329-344.

Rajendran, L. and Annaert, W. (2012). Membrane trafficking pathways in Alzheimer's disease. Traffic 13, 759-770. 
Regen, F., Hellmann-Regen, J., Costantini, E. and Reale, M. (2017). Neuroinflammation and Alzheimer's Disease: Implications for Microglial Activation. Curr Alzheimer Res 14, 11401148.

Rhode, J., Fogoros, S., Zick, S., Wahl, H., Griffith, K. A., Huang, J. and Liu, J. R. (2007). Ginger inhibits cell growth and modulates angiogenic factors in ovarian cancer cells. BMC Complement Altern Med 7, 44.

Richman, M., Wilk, S., Chemerovski, M., Wärmländer, S. K., Wahlström, A., Gräslund, A. and Rahimipour, S. (2013). In vitro and mechanistic studies of an antiamyloidogenic selfassembled cyclic D, L-alpha-peptide architecture. J Am Chem Soc 135, 3474-3484.

Saenghong, N., Wattanathorn, J., Muchimapura, S., Tongun, T., Piyavhatkul, N., Banchonglikitkul, C. and Kajsongkram, T. (2012). Zingiber officinale Improves Cognitive Function of the MiddleAged Healthy Women. Evid Based Complement Alternat Med 2012, 383062.

Sardar Sinha, M., Ansell-Schultz, A., Civitelli, L., Hildesjö, C., Larsson, M., Lannfelt, L., Ingelsson, M. and Hallbeck, M. (2018). Alzheimer's disease pathology propagation by exosomes containing toxic amyloid-beta oligomers. Acta Neuropathol 136, 41-56.

Selkoe, D. J. and Hardy, J. (2016). The amyloid hypothesis of Alzheimer's disease at 25 years. EMBO Mol Med 8, 595-608.

Semwal, R. B., Semwal, D. K., Combrinck, S. and Viljoen, A. M. (2015). Gingerols and shogaols: Important nutraceutical principles from ginger. Phytochemistry 117, 554-568.

Sengupta, U., Nilson, A. N. and Kayed, R. (2016). The Role of Amyloid-beta Oligomers in Toxicity, Propagation, and Immunotherapy. EBioMedicine 6, 42-49.

Sharifi-Rad, M., Varoni, E. M., Salehi, B., Sharifi-Rad, J., Matthews, K. R., Ayatollahi, S. A., Kobarfard, F., Ibrahim, S. A., Mnayer, D., Zakaria, Z. A., Sharifi-Rad, M., Yousaf, Z., Iriti, M., Basile, A. and Rigano, D. (2017). Plants of the Genus Zingiber as a Source of Bioactive Phytochemicals: From Tradition to Pharmacy. Molecules 22.

Sholts, S. B., Smith, K., Wallin, C., Ahmed, T. M. and Wärmländer, S. (2017). Ancient water bottle use and polycyclic aromatic hydrocarbon (PAH) exposure among California Indians: a prehistoric health risk assessment. Environmental health : a global access science source 16, 61.

Wallin, C., Sholts, S. B., Österlund, N., Luo, J., Jarvet, J., Roos, P. M., Ilag, L., Gräslund, A. and Wärmländer, S. K. T. S. (2017). Alzheimer's disease and cigarette smoke components: effects of nicotine, $\mathrm{PAHs}$, and $\mathrm{Cd}(\mathrm{II}), \mathrm{Cr}(\mathrm{III}), \mathrm{Pb}(\mathrm{II}), \mathrm{Pb}(\mathrm{IV})$ ions on amyloid-beta peptide aggregation. Sci Rep 7, 14423.

Wang, S., Zhang, C., Yang, G. and Yang, Y. (2014a). Biological properties of 6-gingerol: a brief review. Nat Prod Commun 9, 1027-1030.

Wang, X., Wang, W., Li, L., Perry, G., Lee, H. G. and Zhu, X. (2014b). Oxidative stress and mitochondrial dysfunction in Alzheimer's disease. Biochimica et biophysica acta 1842, 12401247.

Wärmländer, S., Tiiman, A., Abelein, A., Luo, J., Jarvet, J., Söderberg, K. L., Danielsson, J. and Gräslund, A. (2013). Biophysical studies of the amyloid beta-peptide: interactions with metal ions and small molecules. Chembiochem 14, 1692-1704.

Wärmländer, S. K., Sholts, S. B., Erlandson, J. M., Gjerdrum, T. and Westerholm, R. (2011). Could the health decline of prehistoric California indians be related to exposure to polycyclic aromatic hydrocarbons (PAHs) from natural bitumen? Environ Health Perspect 119, 1203-1207.

Wärmländer, S. K. T. S., Österlund, N., Wallin, C., Wu, J., Luo, J., Tiiman, A., Jarvet, J. and Gräslund, A. (2019). Metal binding to the Amyloid- $\beta$ peptides in the presence of biomembranes: potential mechanisms of cell toxicity. Journal of Biological Inorganic Chemistry 24, 1189-1196.

Zeng, G. F., Zong, S. H., Zhang, Z. Y., Fu, S. W., Li, K. K., Fang, Y., Lu, L. and Xiao, D. Q. (2015). The Role of 6-Gingerol on Inhibiting Amyloid beta Protein-Induced Apoptosis in PC12 Cells. Rejuvenation Res 18, 413-421.

Österlund, N., Kulkarni, Y. S., Misiaszek, A. D., Wallin, C., Krüger, D. M., Liao, Q., Mashayekhy Rad, F., Jarvet, J., Strodel, B., Wärmländer, S. K. T. S., Ilag, L. L., Kamerlin, S. C. L. and Gräslund, A. 
(2018a). Amyloid-beta Peptide Interactions with Amphiphilic Surfactants: Electrostatic and Hydrophobic Effects. ACS Chem Neurosci 9, 1680-1692.

Österlund, N., Luo, J., Wärmländer, S. K. T. S. and Gräslund, A. (2018b). Membrane-mimetic systems for biophysical studies of the amyloid-beta peptide. Biochim Biophys Acta Proteins Proteom.

Dominy, S.S., Lynch, C., Ermini, F., Benedyk, M., Marczyk, A., Konradi, A., Nguyen, M., Haditsch, U., Raha, D., Griffin, C., Holsinger, L.J., Arastu-Kapur, S., Kaba, S., Lee, A., Ryder, M.I., Potempa, B., Mydel, P., Hellvard, A., Adamowicz, K., Hasturk, H., Walker, G.D., Reynolds, E.C., Faull, R.L.M., Curtis, M.A., Dragunow, M., Potempa, J., 2019. Porphyromonas gingivalis in Alzheimer's disease brains: Evidence for disease causation and treatment with smallmolecule inhibitors. Sci Adv 5, eaau3333.

Frozza, R.L., Lourenco, M.V., De Felice, F.G., 2018. Challenges for Alzheimer's Disease Therapy: Insights from Novel Mechanisms Beyond Memory Defects. Front Neurosci 12, 37.

Querfurth, H.W., LaFerla, F.M., 2010. Alzheimer's disease. N Engl J Med 362, 329-344.

Rajendran, L., Annaert, W., 2012. Membrane trafficking pathways in Alzheimer's disease. Traffic 13, 759-770. 